\title{
Fire Management in Fens and Wet Grasslands Grazed by Cattle
}

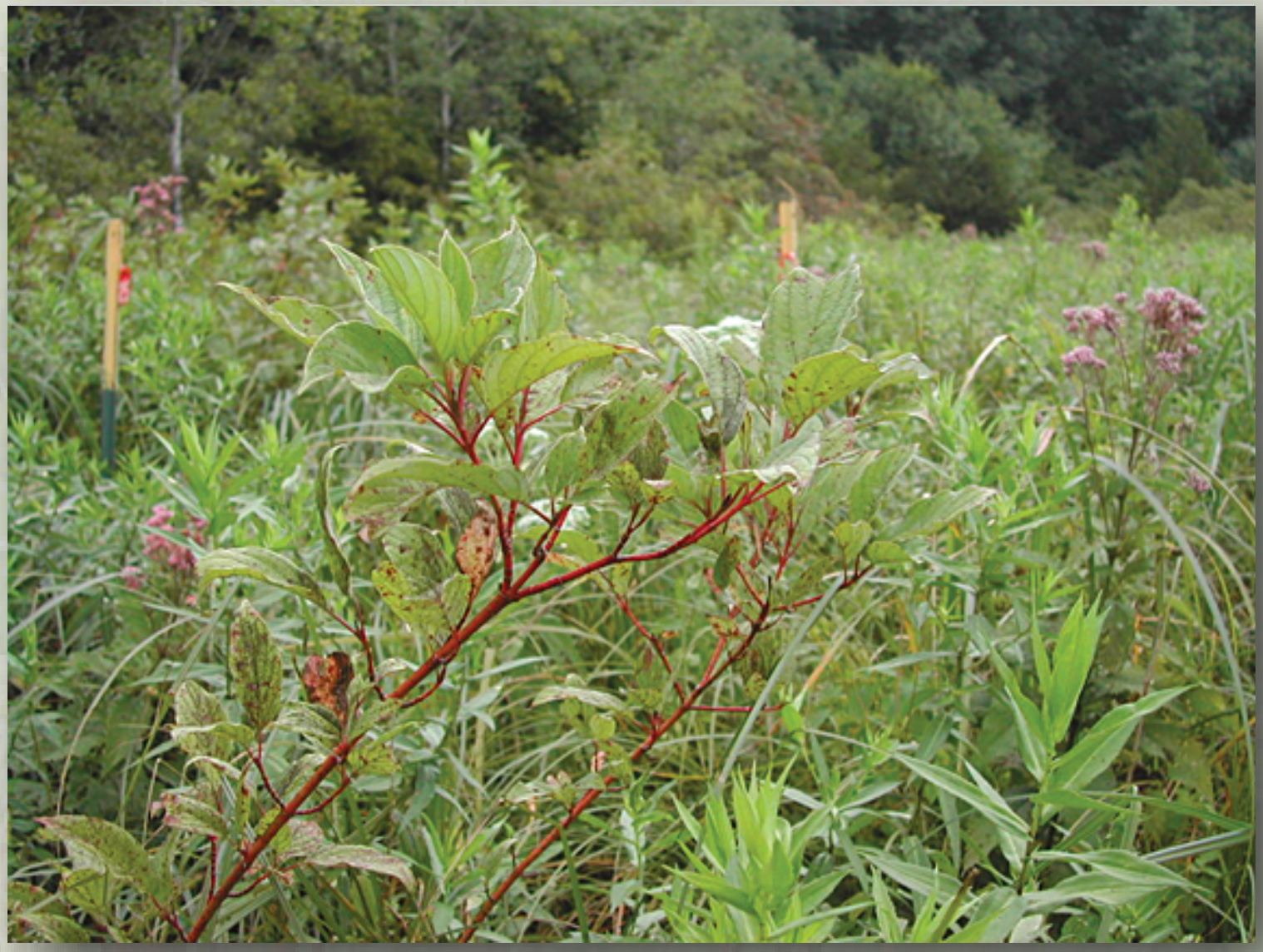

Open-File Report 2006-1268 


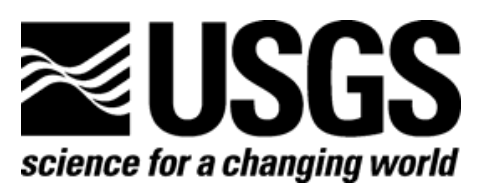

\title{
Fire Management in Fens and Wet Grasslands Grazed by Cattle
}

\author{
By Beth A. Middleton
}

Open-File Report 2006-1268

\section{U.S. Department of the Interior}

U.S. Geological Survey 


\section{U.S. Department of the Interior \\ DIRK KEMPTHORNE, Secretary}

\section{U.S. Geological Survey \\ P. Patrick Leahy, Acting Director}

U.S. Geological Survey, Reston, Virginia 2006

For product and ordering information:

World Wide Web: http://www.usgs.gov/pubprod

Telephone: 1-888-ASK-USGS

For more information on the USGS - the Federal source for science about the Earth, its natural and living resources, natural hazards, and the environment:

World Wide Web: http://www.usgs.gov

Telephone: 1-888-ASK-USGS

Suggested citation:

Middleton, B.A., 2006, Fire management in fens and wet grasslands grazed by cattle: U.S. Geological Survey Open-File Report 2006-1268, 2 p.

Any use of trade, product, or firm names is for descriptive purposes only and does not imply endorsement by the U.S. Government. 


\title{
Fire Management in Fens and Wet Grasslands Grazed by Cattle
}

\author{
By Beth A. Middleton ${ }^{1}$
}

Managers grapple with the problem of shrub invasion in fens and wet grasslands, and the invasion of shrubs is a particular problem in newly acquired natural areas that were once grazed by cattle. Cattle grazing can cause shrub invasion by allowing the seedlings of shrubs, such as Redosier dogwood (Cornus sericea), an opportunity to invade after sedge (Carex stricta) tussocks are damaged by cattle and more light enters through the damaged canopy of the tussocks (fig. 1; Middleton, 2002a). In these wetlands, the biodiversity of forb species decreases as shrubs grow and increase the shade over the tussocks (Middleton, 2002a). Heavily grazed fens often have greatly reduced biodiversity (Middleton and others, in press), and such fens may need to be burned to reduce shrubs and then reseeded or planted with forbs as part of the restoration project. If such wetlands have been ditched or drained, burning may not be an option because the peat may catch on fire (Middleton and others, in press). Alternatively, drained fens can be mowed with a cutting machine or cut by hand. In Europe, handcutting of the vegetation of fens and wet grasslands is used to increase the biodiversity of forbs, and this practice is successful as long as previous cattle grazing has been relatively minor (Middleton and others, in press). Handcutting may be an option for the management of small wetlands, especially if volunteers are available. Also, it is important to remember that some amount of shrub cover is desirable in fens to create a mosaic of habitats.

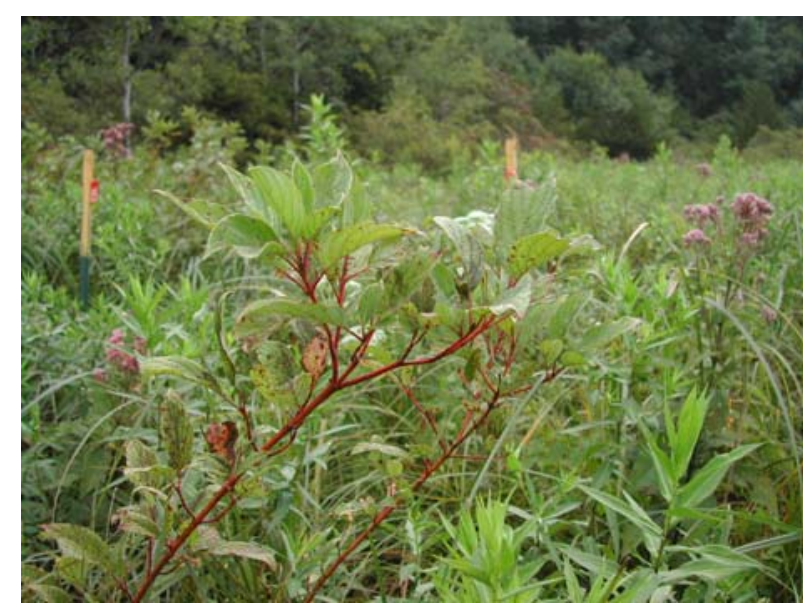

Figure 1. Redosier dogwood (Cornus sericea), a shrub that dominates fens after cattle grazing.

Fires during very wet periods or during winter periods are not as effective in removing shrubs as are hot spring fires (Middleton, unpublished data). While fire increases forb flowering and density (Middleton, 2002b), the effects of fire only persist for 1 to 2 years (Kost and DeSteven, 2000). Ten years after a fire, the forb density begins to decrease again (Bowles and others, 1996). Therefore, from

\footnotetext{
${ }^{1}$ U.S. Geological Survey, National Wetlands Research Center, 700 Cajundome Boulevard, Lafayette, LA 70506
} 
the perspective of the biodiversity conservation of fens and wet grasslands, it is important that these wetlands be mowed, cut by hand, or burned at least every few years (Middleton and others, in press).

The specific management for any particular fen or wet grassland depends greatly on its previous land-use history. Managers should have a clear understanding of the grazing and drainage history of newly acquired fens and wet grasslands so that well-informed management decisions can be made.

\section{References Cited}

Bowles, M., McBride, J., Stoynoff, N., and Johnson, K., 1996, Temporal changes in vegetation composition and structure in a fire-managed prairie fen: Natural Areas Journal, v. 16, p. 275-288.

Kost, M.A., and DeSteven, D., 2000, Plant community responses to prescribed burning in Wisconsin sedge meadows: Natural Areas Journal, v. 20, p. 36-45.

Middleton, B.A., 2002a, Nonequilibrium dynamics of sedge meadows grazed by cattle in southern Wisconsin: Plant Ecology, v. 161, p. 89-110.

Middleton, B.A., 2002b, Winter burning and the reduction of Cornus sericea in sedge meadows in southern Wisconsin: Restoration Ecology, v. 10, p. 1-8.

Middleton, B.A., Holsten, B., and van Diggelen, R., in press, Grazing of fens: a desirable management option?: Applied Vegetation Science. 